\title{
1 Title: Corneal Sensitivity after Ocular Surgery
}

2 Authors:

3 Edward Lum PhD BOptom FAAO

4 The University of New South Wales, School of Optometry and Vision Science, Sydney, Australia

5 Melanie C Corbett MD FRCS FRCOphth

6 The Western Eye Hospital, Imperial Healthcare Trust, London, United Kingdom

7 Paul J Murphy PhD FCOptom, FAAO, FEAOO

8 University of Waterloo, School of Optometry and Vision Science, Waterloo, Canada

9 Cardiff University, School of Optometry and Vision Sciences, Cardiff, United Kingdom

10 Corresponding author: Dr. Edward Lum, School of Optometry and Vision Science,

11 University of New South Wales, Sydney, NSW 2052, Australia.

12 Telephone \#: +612 9385 4613, FAX: +61293136243. email: e.lum@unsw.edu.au

14 Acknowledgments: none

15

16 Disclosures: E.Lum, none; M.Corbett, none; P.J.Murphy, none. No conflicting relationship 17 exists for any author. 


\section{Abstract}

2 The cornea is densely innervated with free nerve endings to provide a high level of sensitivity

3 to foreign bodies or noxious substances. They also provide trophic support to the tissues of the

4 cornea and facilitate their repair and replacement. Any reduction in the function of the nerve

5 endings through disease, contact lens wear or surgery may lead to corneal disease, damage or

6 reduced healing. Assessment of the corneal nerve function can be made by the use of

7 specialised instruments (aesthesiometers) that stimulate the corneal nerves using different

8 modalities - mechanical, chemical, thermal. Each modality assesses the function of a different

9 cohort of corneal nerve type. Ocular surgery, particularly corneal surgery, can produce

10 significant damage to the corneal innervation. However, for the majority of surgical

11 procedures, corneal sensation eventually returns to pre-operative levels given enough time.

12 The principal exceptions to this are penetrating keratoplasty, epikeratophakia and cryo-

13 keratomileusis, where sensation rarely returns to normal. For all types of surgery, the pattern

14 of corneal sensation loss and recovery depends on the type, depth and extent of incision since

15 these influence the number of nerve fibres severed, and on the healing response of the patient. 
Introduction

19 The human cornea is a densely-innervated tissue that provides a high level of sensitivity for

20 ocular protection through the detection of foreign objects or noxious substances. Corneal

21 innervation also plays an important role in the trophic maintenance and repair of the cornea.

22 Any alterations to normal innervation of the cornea will not only lessen the ability to detect

23 objects or substances that could damage the eye, but also reduce its wound-healing ability.

24 Reduction in corneal sensitivity may occur from the desensitisation of nerve fibres, such as

25 during contact lens wear, or from nerve damage during the progression of specific corneal and

26 ocular diseases. The treatment can potentially cause further compromise of the existing corneal

27 innervation. In most cases, however, there are complex processes of re-innervation during the

28 recovery stage following treatment, which may be partial or complete, but which commonly

29 occurs over a prolonged period.

30 Recent times have seen a proliferation in the variety of procedures for the treatment of ocular

31 disease, conditions and refractive error. Current surgical techniques, however, still impact on corneal sensitivity, having different effects on corneal sensation which depend upon the

33 location, size, depth, and orientation of surgical incisions to the ocular surface.

\section{Corneal Innervation and Measurement of Sensitivity}

35 The cornea is a highly specialised tissue that performs four roles in the eye: 1) transparency,

36 allowing light to enter the eye; 2) refraction, focussing the light entering the eye; 3 ) containment

37 of intraocular structures; and 4) protection of the eye against trauma. The protection of this essential organ is achieved in a gross manner by the eyebrows, eyelids and eyelashes, and avoidance responses to objects seen to approach the eye. Also of importance is the extremely sensitive network of fine nerve endings within the corneal epithelium. These nerve endings detect any potential noxious agent present on the corneal surface, stimulating lid closure and tear production. 
43 The quality of the epithelial nerve sensitivity can be assessed by measuring how well the nerves

44 respond to various stimuli, such as mechanical probing, in the form of a nylon thread, ${ }^{12}$ a

45 thermally-cooling air-pulse, ${ }^{3}$ or to mechanical, thermal (warming) or chemical stimuli

46 presented pneumatically.45 The ability to assess corneal sensitivity has allowed the

47 investigation of various different physiological, pathological and surgical factors on corneal

48 nerve function..$^{\cdot 9}$

49 During surgery, damage to nerve function can be minimised by using short, shallow, linear

50 incisions that avoid cutting across the radially oriented corneal nerves. Shorter incisions reduce

51 both the damage caused and the extent of healing required in the cornea post-operatively.

52 However, most incisions are circumferential, which can sever many nerve fibre bundles.

53 Excimer laser refractive surgery (PRK, LASIK, LASEK) affects the cornea and its sensory

54 nerve network in a very different way. The reshaping of the anterior corneal surface involves

55 the removal of a large volume of corneal tissue, over a wide surface area..$^{10.11}$ As a consequence,

56 the epithelial sensory nerves are significantly affected within the treatment zone.

57 Innervation of the Cornea

58 The corneal epithelium has the highest nerve density of free nerve endings of any tissue in the

59 body: 300-600 times that of the skin, and 20-40 times that of dental pulp. ${ }^{22}$ This extensive

60 network of fine nerve endings produces an exquisitely sensitive response to any mechanical,

61 thermal or chemical stimulus..2 The nerves also play a role in the maintenance and health of

62 the corneal epithelium. A reduction in corneal nerve supply will result in impaired wound

63 healing, decreased epithelial metabolism and reduced epithelial cell adhesion (e.g.

64 neurotrophic keratopathy). ${ }^{13.14}$ In addition, impairment of the corneal nerves disrupts the

65 feedback loop for basal tear production, leading to diminished lacrimal secretion and blink

66 reflex, with subsequent drying of the ocular surface..$^{15-18}$ 
68 The corneal nerves are derived from the nasociliary nerve, which is a branch of the ophthalmic 69 nerve, derived from the first division of the Vth cranial nerve (Trigeminal). The nerves 70 supplying the cornea pass along the long ciliary nerve, which is a branch of the nasociliary 71 nerve. They penetrate the posterior sclera, then pass between the sclera and choroid, coursing anteriorly to provide the sensory supply for the cornea, iris, ciliary body, trabecular meshwork and sclera.

Upon reaching the corneal limbus, the nerves produce an annular limbal plexus then join one of two nerve systems. Approximately 50-90 deeper nerve trunks enter the mid-stroma radially, at an average depth of $293 \pm 106 \mu \mathrm{m}$, from various sites around the corneal circumference. More superficial nerves enter the posterior epithelium as finer nerves that contribute to the peripheral subbasal nerve plexus. ${ }^{19}$ Each mid-stromal trunk contains 900 to 1200 myelinated and unmyelinated axons of diameter $0.5-5 \mu \mathrm{m}$, which travel centripetally, mainly in the superficial $150 \mu \mathrm{m}$ of the anterior stroma.$^{20}$ The posterior stroma contains only small-tomedium diameter nerve bundles and scattered individual axons. ${ }^{21}$ However, this lower nerve density is still sufficient to provide axons from which new nerves can re-innervate the remaining cornea after anterior stromal surgery.

84 The myelinated nerves lose their myelin sheath soon after entering the stroma. ${ }^{22}$ As these axons 85 pass towards the epithelium, they ramify and divide to form a poorly characterised subepithelial plexus in the superficial stroma. ${ }^{12199^{23}}$ Anteriorly-directed nerves emerge from the subepithelial plexus, at an average of $204 \pm 58$ sites, to enter the basal epithelial cell layer. ${ }^{1924}$ As they do so, the nerve bundles lose their remaining Schwann cell coverings. These nerves then combine in bundles with peripheral nerves from the limbal plexus, which enter the basal epithelium from the limbus, to form the sub-basal nerve plexus. ${ }^{25}$ The sub-basal nerve plexus

91 lies between the epithelial basal cells and Bowman's layer, and typically runs parallel to the 
92 corneal surface in a whorl-like pattern..$^{26}$ In some cases, the path of the nerve fibres deforms

93 the lateral or basal borders of the basal cells, such that the fibres appear to be fully enclosed.

94 Each nerve fibre contains from 1-40 axons..$^{2425}$ The fibres are of four different types - mechano-

95 sensory, polymodal, mechano-heat and 'cold' neurones - and are arranged within the corneal

96 epithelium according to their type. ${ }^{27.829}$ For the measurement of corneal sensitivity, there are

97 two principal nerve types that mediate the corneal nerve response: Ad fibres that remain in the sub-basal nerve plexus, and $\mathrm{C}$ fibres that turn upwards from this plexus towards the surface. ${ }^{30}$

99 Ad fibres are large diameter $(8-10 \mu \mathrm{m})$, straight nerves that respond primarily to mechanical 100 stimuli, while $\mathrm{C}$ fibres are small diameter $(5-8 \mu \mathrm{m})$, beaded nerves that respond to thermal and chemical stimuli (Figure 1)..$^{5273132333}$

102 Within the epithelium the anteriorly-oriented fibres in the basal epithelial layer pass through

103 the wing-cell layer towards the superficial cells, where they end in fine, unspecialised, nerve

104 endings. These free terminals are usually swollen and can be found throughout the depth of 105 the epithelium. Some of the nerve endings in the superficial layer can extend up to the last desmosomal junction between two superficial cells and are separated from the external environment only by this junction. ${ }^{122334}$

108 Corneal Nerve Repair Mechanisms

109 The repair of the corneal nerve supply generally occurs in two phases, although the pattern and 110 timing of the process varies with the type and extent of initial tissue damage. ${ }^{353637}$ The first phase 111 involves nerves from the undamaged epithelium surrounding the wound, and the second phase 112 originates in the undamaged stroma deep to the wound. During each phase, re-innervation 113 occurs by an initial degeneration of the original fibres within or close to the wound, followed 114 by the regeneration of new terminals and axons into the healing tissue?

115 With a purely epithelial wound, degeneration of damaged nerves occurs rapidly, and any nerves 116 within the wound area will have degenerated by 24 hours after the trauma. By 48 hours, further 
117 degeneration of the nerves in the undamaged stromal plexus occurs, up to approximately

$1180.5 \mathrm{~mm}$ from the wound margin..$^{33.58}$ Simultaneously, at around 16 hours, the first collateral nerve

119 sprouts start growing from the intra-epithelial axons in the undamaged cornea adjacent to the

120 wound. By 24 hours, a dense hyperplasia of these neurites can be seen. The nerve sprouts

121 completely surround the wound and orientate themselves perpendicularly to the edge.

122 Terminals from these sprouts then grow horizontally to enter the basal cell layer of the newly

123 repaired epithelium within the wound area. The purpose of these temporary neurites is not

124 known, but they may result from the increased release of epithelial neurotrophic factor. ${ }^{3639}$

125 The second phase of the re-innervation process begins around 7 days after the injury and can extend for 14-21 days depending on the extent of the original injury. New nerve growth develops in the stromal plexus of the surrounding undamaged cornea. New terminals grow obliquely into the newly-formed, reorganised epithelium from the damaged stumps of the

129 original axons that had innervated the area. At the same time as these new nerve endings are 130 developing, the nerve sprouts formed in the first phase begin to degenerate and have 131 disappeared entirely by 3 weeks. The second phase re-innervation re-establishes a normal 132 pattern of corneal epithelial innervation within about 4 weeks, although tactile sensitivity will 133 still be below normal levels for some time..$^{3640}$

134 Peri-limbal and deeper stromal wounds that damage the main ciliary nerve bundles at the 135 limbus (e.g. cataract surgery) or portions of the stromal nerve supply (e.g. penetrating 136 keratoplasty) will inevitably produce longer lasting damage to the epithelial nerve supply. All

137 those nerves distal to the incision will degenerate producing an immediate loss of corneal 138 sensitivity. Collateral growth of new nerve sprouts from undamaged axons occurs, but is much 139 reduced and nearly all of the new nerve growth develops from the stromal nerve stumps that 140 pass through the wound scar. The re-modelling takes at least 60 days to occur, and the resulting innervation density will be lower than normal. The whole nerve supply architecture will remain 
142 distorted even after 30 months..$^{3,40}$ The recovery of sensitivity will be slow, and may never

143 return to previous levels, depending on the type and extent of the damage. ${ }^{41}$

\section{Measurement of Corneal Sensitivity}

145 The Cochet-Bonnet Aesthesiometer (CBA) is the most common method for assessing corneal

146 sensitivity. Introduced in 1960 , the instrument uses a thin nylon thread (diameter $0.12 \mathrm{~mm}$ ) to

147 apply a direct mechanical stimulus to the corneal nerves. The technique relies on the resistance

148 of the thread to bending. As the thread is gently pressed against the corneal surface, the force

149 required to bend the thread is transferred to the cornea. A variation in the intensity of this

150 stimulus is achieved by varying the length of the nylon thread, which in turn alters the force

151 that must be applied to produce a bend in the thread - the shorter the thread, the greater the

152 force required.

153 Although this instrument has become the standard method for assessing corneal sensitivity,

154 there are major deficiencies in its design and this has led to the development of newer

155 instruments. ${ }^{42,43,4}$ The Draeger Electronic-Optic Aesthesiometer used a fine metal wire attached

156 to a solenoid motor to apply varying stimulus intensities to the cornea. ${ }^{45}$ It produced a stimulus

157 similar to the CBA, but was less affected by ambient, environmental influences. The Belmonte

158 Aesthesiometer uses pressurised air mixes, released at the cornea through an air-jet, to stimulate

159 the corneal nerves. ${ }^{46}$ In a series of experiments, this instrument has been used to show that the

160 corneal nerve fibres respond to different stimulus modalities. ${ }^{32,4748}$ The Non-Contact Corneal

161 Aesthesiometer (NCCA) uses a controlled air-pulse, of pre-determined pressure and duration,

162 aimed at the anterior ocular surface to produce a localised cooling of the tear-film. ${ }^{3.49}$ This

163 cooling is transferred to the corneal epithelium where it is detected by the nerves. Mechanical

164 techniques, such as the Cochet-Bonnet and Draeger Aesthesiometers, stimulate the Ad fibres,

165 whereas the NCCA, which produces cooling, predominantly stimulates the C fibres of the 166 corneal innervation. 
167 Corneal sensitivity can be assessed at various locations on the corneal surface, depending on

168 the area of interest. For example, in LASIK a comparison is often made between the centre of

169 the flap and the paracentral area of the flap adjacent to the hinge. However, for the majority of

170 assessments, only the central cornea is measured.

\section{Effects of Ocular Surgery on Corneal Sensation}

172 All types of corneal surgery inevitably alter corneal sensitivity, since the corneal nerve supply

173 will be damaged. The pattern of loss and recovery produced will depend on the type (linear

174 incision, laser excision, thermal laser), depth, location and extent of wound made, since these

175 influence the number of nerve fibres damaged or severed, and on the healing response of the 176 patient. Other types of ocular surgery, such as retinal detachment repair or squint surgery, can

177 also affect the corneal nerve supply..$^{6.9}$

178 Cataract Surgery

179 In cataract surgery the cloudy lens is removed and a new intraocular lens is inserted through

180 an incision at, or just anterior or posterior to the limbus. As the technique has evolved it has 181 been possible for the length of the incision to be reduced.

182 Large Incision Cataract Surgery

183 In large-incision extracapsular cataract surgery the nucleus is removed intact, requiring a full-

184 thickness incision $12-13 \mathrm{~mm}$ long to be made circumferential to the limbus. Corneal sensitivity

185 is severely reduced within the sector of the cornea central to the arc of incision..$^{50.525253}$ The 186 incision cuts through both the limbal nerve plexus and the large centripetal nerve fibres. As a 187 result, the corneal epithelium and stroma supplied by these nerves becomes denervated. After 188 such a major insult, the recovery of sensation is slow. Little improvement occurs by 1 year 189 post-operatively, and even at 2 years, sensitivity is below normal in the majority of cases..$^{5455565758}$ 
191 Manual small incision cataract surgery is a technique mainly used in the developing world. It

192 also delivers the nucleus whole, as in extracapsular surgery, but through a smaller, more

193 posterior incision in the sclera. Scleral incisions generally produce less effect on the corneal

194 sensation than corneal incisions..$^{59}$ A straight or curved incision, 6-8mm long, is made $3-4 \mathrm{~mm}$

195 behind the limbus, and a tunnel is fashioned to enter the anterior chamber at the level of

196 Schwalbe's line. No significant reduction in corneal sensitivity occurs in the central or 4 mid-

197 peripheral quadrants in the first 2 weeks postoperatively. ${ }^{60}$

198 Rarely, patients undergoing cataract extraction cannot be given an intraocular lens, in which

199 case they may be fitted with a contact lens. Both rigid gas permeable lenses and soft lenses

200 reduce corneal sensation, ${ }^{6,61}$ so it is important to monitor corneal health in these patients as for

201 any other contact lens wearer.

202 With the advent of phacoemulsification and foldable intraocular lenses, cataract surgery can be

203 performed through a small $2-3 \mathrm{~mm}$ tunnel incision. This still reduces corneal sensitivity, but

204 over a much smaller area and is possibly followed by a quicker recovery ${ }^{62}$ This pattern is also

205 evident in patients who undergo a surgical iridectomy, or a trabeculectomy which is performed

206 in the anterior sclera. The smaller incision arc causes less nerve damage, and the sensitivity

207 loss is generally limited to corneal locations at the central and peripheral cornea adjacent to the

208 incision site. ${ }^{63}$ Recovery to pre-operative normal levels usually occurs between 3 to 9

209 months. ${ }^{56,6455}$ This is delayed by the presence of dry eye disease prior to surgery ${ }^{66}$ and accelerated

210 with the topical applications of cyclosporine-A post-operatively to treat dry eye. ${ }^{67}$ Recovery

211 does not appear to be influenced by the mechanism of phacoemulsification occurring at the tip,

212 as shown in a recent study that compared torsional technology to conventional longitudinal

213 movement of the tip..$^{8}$

214 Small Corneal Tunnel Incision for Phacoemulsification Surgery 
215 Small incision cataract surgery is sometimes combined with limbal relaxing incisions (LRIs)

216 to address pre-existing corneal astigmatism. These arcuate incisions at $90 \%$ depth can also

217 produce a sector of reduced corneal sensation, in a similar way to more central arcuate

218 keratotomies (see below).

219 Corneal Transplantation

220 The reduction in sensitivity following corneal transplantation depends upon the depth and

221 thickness of the tissue removed and replaced. There is a spectrum of procedures ranging from

222 full thickness penetrating keratoplasty (PK), through lamellar procedures in which the anterior

223 or posterior layers are replaced, to overlays (tectonic grafts or epikeratophakia) with minimal

224 removal of tissue. In all these procedures, the donor cornea inevitably has no innervation

225 immediately after surgery.

226 Penetrating and Deep Anterior Lamellar Keratoplasty

227 In PK, removal of the central corneal button from the host will damage the remnant nerves in

228 the adjacent host corneal tissue. Although the host corneal epithelium and the sub-epithelial nerve plexus quickly recover, re-innervation of the stroma takes longer ${ }^{6970}$ In nerve regeneration following simple corneal incisions, new nerves grow towards the central cornea along the

231 channels that the degenerated nerves had used. This speeds the regenerative process, and 232 ensures that the new nerve ends don't have to burrow through the densely-packed, stromal 233 collagen lamellae to establish a new path. However when the tissue is replaced, as in transplantation, the nerves that are present in the peripheral host cornea do not align with the

235 channels in the graft. Re-innervation is severely restricted and any recovery of sensation occurs 236 slowly, being initiated at the periphery, with a gradual progression towards the centre of the 237 graft..$^{7071,127,3,7,475}$ This pattern emphasises the importance of a fully-functional stromal nerve supply, 238 in addition to the sub-epithelial plexus, in the recovery of a normal corneal sensitivity. 
239 Although some re-innervation of the corneal epithelium over the graft must occur from the un-

240 damaged peripheral corneal epithelium, this is insufficient to provide a full level of sensation.

241 The earliest that central corneal sensitivity is detectable within the graft is 18 months post-

242 operatively. In a study by Macalister et al, ${ }^{76} 66 \%$ of subjects had no central sensitivity and only

$2439 \%$ had normal sensitivity at 4 years post-operatively. By 7 years, $39 \%$ were still without any

244 measurable sensitivity. Rao et al..$^{22}$ found that the graft can remain completely anaesthetic, or

245 hypoaesthetic, even 32 years after transplantation.

246 Two studies have shown that there is no difference in the rate of recovery of sensation between

247 PK and deep anterior lamellar keratoplasty (replacement of 90-96\% of corneal thickness). In

248 both procedures, Lin et al ${ }^{77}$ found that sensitivity was reduced 12 months post-operatively, and

249 Ceccuzzi et $\mathrm{al}^{78}$ reported a $91 \%$ recovery to pre-surgery levels after 2 years post-operatively.

250 Darwish et al, ${ }^{79}$ however, measured sensitivity changes using the NCCA (which stimulates C

251 fibres rather than Ad fibres) and found levels not significantly different to pre-surgery baseline

252 at 12 months. This suggests that recovery rates differ between the different nerve fiber types.

253 Al-Aqaba et al ${ }^{\text {so }}$ performed a histochemical analysis on 12 failed full-thickness corneal grafts

254 of mean survival duration of 6.4 years. The study found evidence of abnormal architecture and

255 orientation of corneal nerves that persisted 14 years after surgery. It also showed that

256 regenerated stromal nerves remained in the stroma, and did not contribute to epithelial

257 innervation. Long-term alterations in corneal nerve morphology were confirmed in studies

258 using in vivo confocal microscopy. ${ }^{81.12}$ One study found that the sub-basal nerve density was

259 still reduced 40 years post-surgery. ${ }^{81}$ It seems that patients can expect some neural recovery,

260 but that the majority will be left with a sub-normal level of sensitivity. ${ }^{8376}$

261 Posterior lamellar keratoplasty

262 A posterior lamellar or endothelial keratoplasty is used in conditions where there is purely an insufficiency of the endothelium, such as Fuchs corneal dystrophy. The host Desçemet's 
membrane and endothelium are replaced by those from a donor, thereby retaining the neural structure of the anterior host cornea following surgery. Only two studies have investigated the effect of this procedure on corneal sensitivity. Kumar et al. ${ }^{84}$ demonstrated relative preservation of corneal sensitivity after Descemet stripping automated endothelial keratoplasty (DSAEK) technique. However, Ahuja et al ${ }^{85}$ found sensitivity was reduced compared to pre-operative levels using a similar surgical technique (Descemet stripping endothelial keratoplasty, DSEK).

The same study found that, although sensitivity recovered to pre-surgery levels within 3 years, it did not improve to levels similar to normal corneas. ${ }^{85}$ This suggests that nerve loss in the host periphery prior to surgery due to persistent oedema or scarring was long-lasting.

273 Patients awaiting corneal transplant and suffering from symptomatic bullous keratopathy may have recurrent corneal erosions treated with anterior stromal puncture. This promotes new adhesion complexes between the epithelium and underlying stroma from the secretion of extracellular matrix proteins ${ }^{86}$ In these cases, there is relief of symptoms, particularly pain, presumably from fewer bullae ruptures. Interestingly, corneal sensitivity improves following the procedure, ${ }^{87}$ suggesting recovery in nerve morphology with the improved corneal surface. Arcuate Keratotomy

An arcuate keratotomy incision is a short $(3-7 \mathrm{~mm})$ circumferential corneal incision addressing astigmatism, for example following corneal transplantation. It is made at a diameter of $6-7 \mathrm{~mm}$ and to only $90-95 \%$ depth. There is a sectoral loss and recovery of sensitivity confined to the portion of the cornea central to the incisions, as in cataract surgery. Shivitz and Arrowsmith ${ }^{88}$ found that, with an incision of less than $80 \%$ corneal thickness, $72.8 \%$ of patients had a normal sensitivity after 1 year, whereas with $90 \%$ corneal thickness incisions, no recovery of sensation was measured after the same time period. Increasing the number of incisions also slows the recovery. However, in general, corneal sensitivity returns to normal levels by 1 year postoperatively ${ }^{38.888389}$ Studies involving animals have shown the faster recovery of experimentally 
damaged nerves with the topical application of therapeutic agents, such as semaphoring $3 \mathrm{~A}$

290 inhibitor, pituitary adenylate cyclase-activating polypeptide, ${ }^{91}$ macrophage migration

291 inhibitory factor, ${ }^{92}$ nerve growth factor, ${ }^{93}$ drug FK962, ${ }^{, 4}$ and pigment epithelial-derived factor

292 plus docosahexaenoic acid.95

293 Tectonic Overlay Grafts and Epikeratophakia

294 A tectonic corneal graft is performed when a patch of donor tissue is transplanted onto the 295 surface of a host cornea which has an actual or threatened perforation. This typically occurs 296 as a result of severe corneal inflammation or previous infection, and the aim is to restore the 297 integrity of the globe. There are no studies of corneal sensitivity after such procedures, but we can extrapolate from studies on epikeratophakia and cryo-keratomileusis. Epikeratophakia is a refractive surgery technique that involves the grafting of a lenticule of donor tissue to the anterior surface of the cornea, but is rarely performed these days. Cryo-keratomileusis is similar, but involves the removal, freezing, re-shaping and re-attachment of a portion of the host cornea. Following epikeratophakia, the new anterior surface has no nerve supply and a new innervation must develop in much the same way as that after penetrating keratoplasty. As a result, the pattern of sensitivity recovery measured is much the same..$^{96979899}$ With cryokeratomileusis, the re-shaped corneal button has undergone freezing in addition to removal from the donor, both of which will have destroyed the corneal nerves. Re-innervation of the corneal button and sensation recovery will also be limited, in a similar manner to keratoplasty..$^{99,100.010102 .103}$ For example, at 5 years post-epikeratoplasty, only minimal corneal sensitivity was measured in the central zone, but by 10 years post-operatively it had

310 significantly returned. However, only $17.7 \%$ of eyes at 10 years had a normal central corneal 311 sensitivity. ${ }^{104}$ Epikeratoplasty may also include a centrally-placed keratectomy, but no

312 difference in loss and recovery has been found between those patients with a keratectomy and 313 those without. 
315 In radial keratotomy, typically 4-8 radial incisions are made in the cornea to flatten its centre

316 to treat myopia. The degree of flattening depends on the type, depth and number of incisions

317 made, and these factors also define the extent of sensitivity loss..$^{38,4,105}$ The normal radial incisions

318 are parallel to the axis of the radiating stromal nerve fibres and so produce minimal damage.

319 Intra Corneal Ring Segments

320 This surgical technique offers a reversible method for the correction of low myopic refractive

321 errors, but is now more commonly used to stabilise the corneal profile in cases of progressive

322 keratoconus. Small PMMA rings are inserted into a channel at two-thirds depth in the mid-

323 peripheral stroma to produce an alteration to the shape of the anterior corneal surface. The

324 epithelial nerves are not affected, and the stromal nerves are untouched superficial and deep to

325 the ring segments. A small 2-3mm radial incision in the cornea allows insertion, but this

326 produces no long-term reduction in corneal sensation, and sensitivity returns to pre-operative

327 levels after 1 year. ${ }^{106}$

328 Excimer Laser Surface Procedures

329 The excimer laser can remove tissue from a large area of the superficial cornea with extreme

330 precision, and with minimal damage to adjacent tissue. It therefore affects the corneal nerve

331 supply in a very different way to a scalpel incision. ${ }^{11,07,108,109}$ It has a role in refractive surgery, and

332 is used to treat certain corneal surface diseases.

333 Photo-refractive Keratectomy

334 Photo-refractive keratectomy (PRK) uses excimer laser technology to directly alter the corneal 335 refractive power over a large surface area. Myopic PRK procedures remove central corneal 336 tissue over a typical treatment zone of $8-8.5 \mathrm{~mm}$ diameter to produce a saucer-shaped excision 337 that is deeper centrally than peripherally. Hyperopic PRK has a wider 'ring-donut' shaped 338 treatment zone approximately $9 \mathrm{~mm}$ in diameter. The majority of tissue is removed in the mid- 
339 peripheral zone, with peripheral blending. In both procedures, the corneal epithelium is

340 manually debrided in the treatment zone, and this removes all of the sensitive epithelial nerve

341 supply. The excimer laser then ablates the exposed stroma to a depth (10-150 $\mu \mathrm{m})$ dependent

342 on the dioptric correction required and the diameter of the ablation zone. ${ }^{110}$ This procedure

343 removes a significant proportion of the anterior stromal nerve supply. As a result, when the

344 corneal epithelium has grown back over the exposed stroma, any re-innervation that takes place

345 can only do so from the peripheral un-touched epithelial supply and the remnant stromal supply

346 deep to the excision.

347 The majority of research into the pattern of corneal sensitivity loss and recovery after photo348 refractive keratectomy has been performed using the CBA or another similar mechanical 349 stimulus, and have therefore considered the surgical effect on the Ad fibres. There have only 350 been a limited number of studies that have assessed the effect on the $\mathrm{C}$ fibres using a thermally351 cooling stimulus. The vast majority of studies have also only considered myopic PRK rather 352 than hyperopic PRK.

353 Myopic PRK

354 The majority of studies on myopic PRK used mechanical stimuli and found a short-term reduction in sensitivity. Sensitivity returned to pre-operative levels by 6 months or even earlier, unless the ablation depth was very deep (approximately $100 \mu \mathrm{m}$, or corrections greater than $-6.00 \mathrm{D})$. For the majority of refractive errors corrected, where the ablation depth was less than $100 \mu \mathrm{m}$, there was no relationship between the pattern of corneal sensation loss and recovery and ablation depth. In contrast, a study that assessed corneal sensitivity to a

360 thermally-cooling stimulus, found that sensitivity did not recover until 1 year after surgery.116

361 This difference may be related to the different neural architecture of the two nerve types that mediate the two stimuli, and how this architecture is changed after PRK. An early histological study in rabbit eyes ${ }^{117}$ and in vivo confocal microscopy studies on human eyes ${ }^{18-120}$ have shown 
the recovery of corneal innervation after PRK to be disorganised. The crude lattice of nerves that re-innervates the corneal epithelium may provide a network more readily able to detect the mechanical surface deformation stimulus of the CBA. In contrast, the cooling stimulus of the

367 NCCA may require a more complete re-organisation of the corneal nerves, with a network of

368 fine $\mathrm{C}$ fibre nerve endings arranged close to the epithelial surface. By necessity this takes longer, and so recovery of the $\mathrm{C}$ fibre sensation would take longer too. weeks after surgery. ${ }^{121}$ No similar findings have been reported for studies on humans. However, hyper-sensitivity of regenerating corneal nerve $\mathrm{C}$ fibres has been reported, ${ }^{122}$ and a study by

373 Gallar et al ${ }^{123}$ found hyper-sensitivity following LASIK. This latter finding has been attributed to the greater stimulus resolution possible with the Belmonte aesthesiometer. It is therefore possible, that there could be some short-term (1-2 weeks) hyper-sensitivity following PRK if measurements were made using a sufficiently sensitive device.

378 Only one published paper has considered the effect of low-powered hyperopic PRK correction on corneal sensation. ${ }^{124}$ This study used the cooling stimulus of the NCCA to assess the loss and recovery of $\mathrm{C}$ fibre mediated sensitivity. Although a similar result might be expected, to that found with myopic PRK, sensitivity was found to not change significantly after surgery. This unusual result can be explained by again considering the effect of surgery on the corneal architecture. Unlike myopic PRK where a large, deep central ablation occurs, in hyperopic PRK the central corneal stroma is preserved and a peripheral ring is ablated. Since the ablations attempted in the study where not deep (2-4 Dioptres), the deeper stromal nerve supply to the central cornea was most-likely preserved. Even with the debridement or ablation of the central epithelial nerve supply, the virtually un-touched stromal nerve supply is sufficient to maintain corneal sensation. However, for this to be confirmed, measurements of corneal sensation at 
both the central cornea and at the area of cornea where maximum ablation depth occurred

390 would need to be taken. The authors also suggested that the short-term hyper-sensitivity of

391 regenerating $\mathrm{C}$ fibres may have masked some of the initial sensitivity loss following corneal

392 epithelium removal.

393 Photo-therapeutic Keratectomy

394 One other important use of excimer laser ablation is for photo-therapeutic keratectomy (PTK).

395 This procedure produces a broad excision of uniform depth, or masking fluid can be used 396 during the removal of proud irregularities. It is used to treat superficial corneal pathological 397 conditions and has a wide variety of indications including removal of band keratopathy or 398 superficial scars and improving epithelial adhesion in recurrent erosion. No attempt is made 399 to alter the patient's refraction. Removal of abnormal tissue can lead to an improvement in 400 corneal sensation after PTK, both in terms of increased sensitivity and a reduction in 401 discomfort. Creation of a smoother corneal surface may also improve tear film quality and 402 conjunctival squamous metaplasia. ${ }^{25}$ Patients with herpetic corneal scarring commonly have 403 reduced corneal sensitivity before the procedure, and therefore unsurprisingly, corneal 404 sensitivity measurements are slightly lower at 6 months compared with other patients.

\section{Excimer Laser Flap Procedures}

406 In refractive procedures under a flap, a layer of epithelium or epithelium plus stroma is raised

407 before the excimer laser refractive correction is applied to the stromal bed, and then the flap is 408 replaced. In contrast to surface treatments, this provides the opportunity for some innervation 409 of the surface layers to remain intact.

\section{$410 \quad$ Laser in-situ Keratomileusis}

411 Laser in-situ keratomileusis (LASIK) is a development of PRK, in which a corneal flap is 412 produced that includes superficial stroma as well as epithelium. A micro-keratome is used to 413 cut through the superficial stroma, creating a thin $(160-180 \mu \mathrm{m}$ thick $)$ flap. This is then peeled 
414 back, exposing the underlying stroma for ablation in a similar way to PRK. The flap is then

415 carefully replaced over the treatment zone. An alternative method for the flap creation is the 416 use of a femtosecond laser, creating a thinner (90-100 $\mu \mathrm{m}$ thick) flap. Further details discussed 417 below.

418 From the point of view of corneal innervation, the micro-keratome cuts through the epithelial 419 nerve supply in the periphery of the flap, and the deep nerve supply across the base of the flap.

420 The only exception to this is in the $45^{\circ}-60^{\circ}$ sector central to the hinge, where the epithelial 421 supply is preserved. This is in contrast to the formally-used procedures of epikeratophakia and 422 cryokeratomileusis, where the flap was totally removed without a hinge and no nerve supply 423 to the flap was retained. In LASIK, the laser ablation will remove the central portion of the stromal nerve supply to an even greater depth.

425 This more complex surgical procedure has produced a mixed set of results. The majority of 426 published studies have found less reduction in sensitivity following LASIK than with 427 PRK. ${ }^{126,127,128,129,130,131,132,133}$ However, this reduction in sensitivity has a longer duration, up to about 6

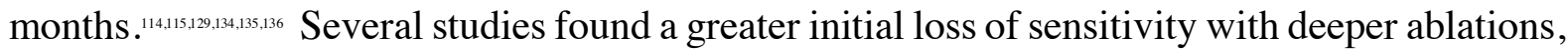
but after 6 months this difference no longer persisted..$^{137,138,139}$ Topical application of cyclosporine ${ }^{140}$ 430 and protein-free calf blood extract ${ }^{141}$ have been shown to speed the recovery of corneal 431 sensitivity following LASIK.

432 This outcome following LASIK can be attributed to the greater preservation of the corneal 433 epithelial and anterior stromal innervation via the hinge of the corneal flap. The sector central 434 to the hinge has some reduction in corneal sensation, but this loss is not as severe, and recovery 435 occurs more quickly, than the centre of the flap and those portions of the flap furthest from the 436 hinge. ${ }^{128,42,43}$ There is some disagreement on the influence of hinge position on corneal 437 sensitivity, with studies showing either less reduction, ${ }^{142,143}$ no difference, ${ }^{14,145,146}$ or greater 438 reduction ${ }^{134}$ in nasal or temporal-hinged eyes compared to superior-hinged eyes. In addition, 
439 Donnenfeld et $\mathrm{al}^{142}$ showed greater loss with a narrower hinge, while Mian et a $\mathrm{l}^{145}$ noted hinge

440 angle and thickness has no effect on sensitivity loss. Nevertheless, it is likely that the prolonged

441 depression in sensitivity reflects the need of the regenerating neurones to re-populate the

442 stromal flap rather than just the new epithelium. As such, it reflects the problems of re-

443 innervation encountered with corneal transplantation. In general, corneal nerve regeneration

444 after LASIK follows a slower pattern than that found after PRK, with a greater delay in the

445 development of new nerve fibres. However, as the nerve fibres become better organised,

446 sensitivity returns to normal levels..$^{150.128 .147}$

447 In recent years, alternative methods to conventional LASIK have developed with the advent of

448 the femtosecond laser for refractive surgery. When used in place of the micro-keratome for

449 flap creation (i.e. FS-LASIK), femtosecond laser cuts have been shown to produce better

450 uniformity and predictability of the flap thickness than conventional LASIK ${ }^{148}$ which results in

451 less damage to the corneal nerves. ${ }^{14,150}$ In the femtosecond lenticule extraction (FLEx)

452 technique, the femtosecond laser is used to create a lenticule within the stroma that is removed

453 with forceps after the flap is lifted. In small incision lenticule extraction (SMILE), the lenticule

454 is removed through a $3-4 \mathrm{~mm}$ opening in the peripheral cornea, rather than a full flap. This has

455 been shown to produce less sub-basal nerve density loss, with faster recovery of corneal

456 sensitivity, ${ }^{151}$ when compared to FS-LASIK ${ }^{152.153 .154}$ and FLEx-treated eyes. ${ }^{155.16 .157}$ Less reduction in

457 corneal sensitivity and faster recovery is found when the standard 70-degree angled laser side

458 cut flap is replaced with an inverted 130-degree cut, ${ }^{\text {iss }}$ presumably because of improved wound

459 healing and apposition of severed nerves from a more stable flap post-surgery. ${ }^{159}$

\section{$460 \quad$ Laser Sub-epithelial Keratomileusis}

461 Laser sub-epithelial keratomileusis (LASEK) was developed for patients considering refractive surgery who have low myopia, thin corneas, or a pre-disposition to flap trauma. LASEK combines elements of both PRK and LASIK techniques. The hinged flap that is made and 
restored following ablation is only a thin epithelial sheet. It is separated from the cornea, using

465 either the application of an alcohol solution, ${ }^{160}$ or an epikeratome. ${ }^{161}$ The excimer laser ablation

466 is then applied to the stromal surface in a similar way to PRK. The deeper stromal nerves are

467 thus spared during the ablation process. Disruption to nerve fibres in the sub-basal, sub-

468 epithelial and anterior stromal layers still occurs following surgery, with the reduction in corneal sensitivity correlating with ablation depth..$^{12,163,164}$ Two studies showed the initial reduction in corneal sensitivity was less and recovery faster after LASEK than conventional LASIK. ${ }^{15.166}$ Another study involving LASEK showed corneal sensitivity recovered faster when the flap was created with an epikeratome compared to using alcohol solution. ${ }^{150}$ Darwish et al, ${ }^{167}$ however, found no such difference between LASIK and LASEK when sensitivity was measured using the NCCA. In addition, Patel et al ${ }^{168}$ found no difference in sensitivity changes between flaps created with the femtosecond laser and the microkeratome using the Belmonte aesthesiometer. Therefore, it appears that LASIK has a greater impact than LASEK on the damage and regeneration of $\mathrm{A} \partial$ fibres, whereas there is no difference between the two techniques on recovery of $\mathrm{C}$ fibers.

Dry eye is a common complaint following all types of photorefractive surgery. Several studies have speculated that post-operative reduction in corneal sensitivity disrupts the feedback loop

481 for basal tear production, leading to diminished lacrimal secretion and poor tear film, which

482 produces dry eye symptoms. . $69,170,17,172,173^{2}$

\section{Collagen Cross-Linking}

484 Cross-linking is a relatively new procedure that can delay or prevent the progression of 485 keratoconus. Debridement of the central cornea epithelium is followed by topical application 486 of riboflavin solution and irradiation of the exposed corneal stroma with Ultraviolet A 487 radiation. ${ }^{174}$ This results in chemical bonding between adjacent collagen lamellae to prevent 488 slippage leading to ectasia. Many studies show a significant loss of corneal sensitivity 
immediately after surgery, followed by a gradual recovery towards pre-operative levels over

490 the ensuing 6 to 12 months. ${ }^{175,17,17,17,178,17,9980}$ Nerve morphology is affected over a similar time course.

491 One study showed that sub-basal nerve density recovers to pre-operative levels after 7 to 12

492 months. However, normal levels were still not reached by 5 years post-operatively ${ }^{181}$ Less

493 reduction and more rapid recovery in corneal sensitivity is achieved when the epithelium is not

494 removed, which is the recommended procedure for patients with less than $400 \mu \mathrm{m}$ corneal

495 thickness. ${ }^{182}$

496 Cyclophotocoagulation

497 This procedure is used to selectively damage the ciliary body to decrease production of aqueous 498 humour, as a treatment for glaucoma. It is accomplished by directing the beam from a 499 neodymium:yttrium-aluminium-garnet (Nd:YAG) laser perpendicular to the sclera at a point $500 \quad 1-2 \mathrm{~mm}$ posterior to the limbus. The beam passes through the sclera and is absorbed by melanin 501 in the pigmented tissue.

502 Pre-existing corneal conditions (e.g. long-term use of topical beta-blockers, corneal surgery 503 with large incision, some corneal dystrophies, high myopia, anterior uveitis or diabetes 504 mellitus) $)^{183}$ may pre-dispose the patient to neurotrophic cornea defects. In severe conditions, 505 this can lead to corneal perforation. ${ }^{184}$ However, changes in corneal innervation or sensation 506 can be reduced by good patient selection and avoidance of the 3 and 9 o'clock limbal regions. ${ }^{185}$ 507 Subjects in this study were pre-selected to exclude corneas with previous complications, 508 diabetes, rheumatoid arthritis, amyloidosis, or herpetic eye disease, and this may have removed 509 those 'at-risk' groups that developed neurotrophic defects observed in other studies. Not 510 exceeding the recommended laser power level of $2500 \mathrm{~mW}$ for $2.5 \mathrm{secs}$ has also been suggested 511 to prevent neurotrophic keratopathy development as a result of nerve damage..$^{183}$

512 In contrast, a study in dogs found a $27.4 \%$ overall reduction in corneal sensitivity in all areas 513 of the cornea, from pre-op levels after 2 weeks. ${ }^{186}$ No measurement was made of recovery time. 
514 Immuno-histochemical analysis of the nerve fibres reported a loss of the major nerve bundles,

515 suggesting that the nerves in the area of laser application are destroyed.

\section{$516 \quad$ Retinal Detachment Surgery}

517 The impact of retinal detachment surgery, which commonly involves pars plana vitrectomy, is

518 not immediately apparent. However, a significant decrease in sensitivity has been found in

519 eyes treated with an encircling band. No significant decrease was found in eyes treated with

520 localised radial or circumferential silicone or sponge explants alone. The mechanism is

521 unclear, but may be due to surgically induced inflammation of the ciliary nerves as they course

522 between the sclera and choroid, or to damage produced by compression of the nerves from the

523 scleral buckle or by surgical perforation. There may be a contribution from post-operative

524 inflammation and surface irregularity as an encircling band requires a full peritomy, whereas

525 local explants require only sectoral incisions of the conjunctiva at the limbus. It is also not

526 clear whether the effect on sensitivity is long-term, as the pattern of recovery does not correlate

527 with time post-operatively. However there may be a lot of variations in the damage to

528 extraocular tissue during similar operations. Most studies find that sensation eventually returns

529 to normal levels..$^{187,88,189,190}$ In eyes treated with circumferential laser photocoagulation, corneal

530 sensitivity may be reduced for 6 months after surgery..$^{191}$ Damage is thought to occur to ciliary

531 nerves in the supra-choroidal space..$^{192.193}$ One paper has raised the possibility of whether the fine

532 nerves in the sub-basal nerve plexus could be damaged as the laser passes through the cornea,

533 but there is no pigment in the cornea to absorb the energy, and the rays are not focussed there. ${ }^{191}$

\section{Strabismus Surgery}

535 Ocular discomfort and dryness is a commonly-reported symptom after strabismus surgery. In

536 the first study to explore the relationship between ocular sensitivity and symptoms, ${ }^{194}$ no change

537 in central corneal sensation was observed. However, conjunctival sensation was reduced after 538 surgery, which persisted during the 3 months duration of the study. This effect was suggested 
to be due to electro-cauterisation of the circum-limbal blood vessels damaging the peri-limbal

540 nerve fibres. A later study found goblet cell density was reduced up to 2 months after surgery,

541 resulting in instability of the ocular tear film and hence another possible cause of ocular

542 irritation symptoms. ${ }^{195}$ A more recent study found more dry eye symptoms and tear film

543 instability with a limbal incision technique than fornix incisions. ${ }^{196}$ Central corneal sensitivity

544 was also reduced following limbal incisions, whereas it was unchanged with fornix incisions,

545 which suggests limbal incisions cause partial denervation of the cornea. Despite the detected

546 adverse effects, all studies found most ocular signs and symptoms recovered to baseline levels

547 within 2-4 months post-surgery.

\section{Conclusions}

549 Transient reductions in corneal sensitivity have been recorded after most types of corneal

550 surgery. Incisions into the ocular surface damage the complex network of superficial nerve

551 fibres and terminals, with greater reductions in sensitivity seen with a greater arc length and

552 depth into the mid-stroma, and if incisions are circumferential rather than radial. Incisions or

553 debridement of the corneal epithelium will result in temporary loss of corneal sensitivity from

554 the damage or removal of the sub-basal and sub-epithelial nerve plexi. Recovery of corneal

555 sensitivity from such procedures to pre-operative levels is generally expected within 6 months

556 for mechanical stimuli, or up to 1 year for thermal or chemical stimuli. Circumferential stromal

557 and limbal incisions, however, cut through deeper trunks of the neural supply to the corneal

558 surface. Although sensitivity loss is confined to the sector of the cornea central to the arc of

559 incision, recovery is generally slower than epithelial procedures. Procedures involving the

560 transplantation of corneal tissue show the slowest recovery due to a lack of alignment of nerve

561 channels between host and donor tissue. A sub-normal level of sensitivity is commonly

562 observed after many years post-operatively. Other types of surgery, such as for squint or retinal

563 detachment, can alter corneal sensitivity by affecting the nerves as they travel towards the 
cornea. In such cases, the severity and recovery time are generally less in comparison to

565 procedures that involve incisions to the ocular surface.

566 To summarise, all types of ocular surgery can affect corneal innervation. However, for the

567 majority of patients, corneal sensitivity can be expected to return to normal levels with time,

568 and only when the most severe damage to the corneal innervation occurs will there be a

569 permanent reduction or absence in corneal sensitivity. Nevertheless, a quick recovery of the

570 corneal nerve function to normal levels is important in the continuing maintenance of a healthy

571 cornea, as several cases of surgically induced neurotrophic epitheliopathy have been

572 recorded, ${ }^{18,187}$ as well as secondary effects on the tear film and contact lens tolerance. It is

573 therefore important that clinicians are aware of this to provide appropriate management,

574 especially in the presence of pre-existing disease that might delay or influence recovery of

575 corneal sensation.

\section{Method of Literature Search}

577 A systematic search was completed using several scientific publication databases. Articles were selected for inclusion that evaluated any aspect of corneal sensation change, as a result of ocular surgery, and each article was critically assessed for the contribution it gave to the understanding of this area. For articles published between 2000 to 2017, articles relevant to corneal sensitivity, ocular surgery interventions, and measurement techniques were found using the search terms outlined in the PubMed search strategy (available on request), which provides the detailed search strategy in PubMed and Ovid Embase. The languages of focus were: English, French, German, Polish, Japanese, Danish, and Russian, however, the database searches were not limited to these, and other languages were considered. Articles prior to 2000 were searched through Medline, ISI Web of Science, and other databases. 
1. Boberg-Ans J. Experience in clinical examination of corneal sensitivity $\mathrm{Br} J$

2. Cochet P, Bonnet R. Corneal esthesiometry: clinical measurement and physiological and pathological changes. La Clinique Ophtalomogique. 1960;4:3-17 (French).

3. Murphy PJ, Patel S, \& Marshall J. A new non-contact corneal aesthesiometer (NCCA). Ophthalmic Physiol Opt. 1996;16:101-107.

4. Beuerman RW, Tanelian DL. Corneal pain evoked by thermal stimulation. Pain. 1979;7:1-14.

5. Gallar J, Pozo MA, Tuckett RP, Belmonte C. Response of sensory units with unmyelinated fibres to mechanical, thermal and chemical stimulation of the cat's cornea. J Physiol. 1993;468:609-622.

6. Millodot M. A review of research on the sensitivity of the cornea. Ophthalmic Physiol Opt. 1984;4:305-318.

7. Assil KK, Quantock AJ. Wound healing in response to keratorefractive surgery. Surv Ophthalmol. 1993;4:305-318.

8. Kohlhaas M. Corneal sensation after cataract surgery and refractive surgery. Refract Surg. 1998;24:1399-1409.

9. Martin XY, Safran AB. Corneal hypoesthesia. Surv Ophthalmol. 1988;33:28-40.

10. Trokel SL, Srinivasan R, Braren B. Excimer laser surgery of the cornea. Am J Ophthalmol. 1983;96:710-715.

11. Gartry DS, Kerr Muir MG, Marshall J. Photorefractive keratectomy with an argon fluoride excimer laser: a clinical study. Refract Corneal Surg. 1991;7:420-435.

12. Rózsa AJ, Beuerman RW. Density and organization of free nerve endings in the corneal epithelium of the rabbit. Pain. 1982;14:105-120.

13. Mishima $S$. The effects of the denervation and stimulation of the sympathetic and the trigeminal nerve on the mitotic rate of the corneal epithelium in the rabbit. Jpn J Ophthalmol. 1957;1:65-73.

14. Beuerman RW, \& Schimmelpfennig B. Sensory denervation of the rabbit cornea affects epithelial properties. Exp Neurol. 1980;69:196-201.

15. Parra A, Gonzalez-Gonzalez O, Gallar J, Belmonte C. Tear fluid hyperosmolality increases nerve impulse activity of cold thermoreceptor endings of the cornea. Pain. 2014;155:1481-1491.

16. Parra A, Madrid R, Echevarria D, et al. Ocular surface wetness is regulated by TRPM8dependent cold thermoreceptors of the cornea. Nat Med. 2010;16:1396-1399.

17. Savini G, Barboni $P$, Zanini $M$, et al. Ocular surface changes in laser in situ keratomileusis-induced neurotrophic epitheliopathy. J Ref Surg. 2004;20:803-809.

18. Wilson S. Laser in situ keratomileusis-induced (presumed) neurotrophic epitheliopathy. Ophthalmology. 2001;108:1082-1087.

19. Marfurt CF, Cox J, Deek S, Dvorscak L. Anatomy of the human corneal innervation. Exp Eye Res. 2010;90:478-492.

20. Tervo K, Latvala $\mathrm{T}$, Tervo $\mathrm{T}$. Recovery of corneal innervation following photorefractive keratoablation. Arch Ophthalmol 1994;112:1466-1470.

21. Marfurt C, Murphy C, Florczak J. Morphology and neurochemistry of canine corneal innervation. Invest Ophthal Vis Sci. 2001;42:2242-2251.

22. Zander E, Weddell G. Observations of the innervation of the cornea. J Anat. 1951;1:6999.

23. Matsuda H. Electron microscopic study on the corneal nerve with special reference to its endings. Jpn J Ophthalmol. 1968;12:163-173. 
24. Ueda S, del Cerro M, LaCascio J, Aquavella J. Peptidergic and catecholaminergic fibers in the human corneal epithelium. An immunohistochemical and electron microscopic study. Acta Ophthalmol. 1989;67:80-90.

25. Auran JD, Koester CJ, Kleiman NJ, et al. Scanning slit confocal microscopic observation of cell morphology and movement within the normal human anterior cornea. Ophthalmology. 1995;102:33-41.

26. Patel DV, McGhee CNJ. Mapping of the normal human corneal sub-basal nerve plexus by in vivo laser scanning confocal microscopy. Invest Ophthalmol Vis Sci. 2005;46:4485-4488.

27. Müller LJ, Pels L, Vrensen GF. Ultrastructural organization of human corneal nerves. Invest Ophthalmol Vis Sci. 1996;37:476-488.

28. Müller L, Vrensen G, Pels L, et al. Architecture of human conreal nerves. Invest Ophthal Vis Sci. 1997;38:985-994.

29. Belmonte C, Garcia-Hirschfeld J, Gallar J. Neurobiology of ocular pain. Prog Retin Eye Res. 1997;16:117-156.

30. MacIver M, Tanelian D. Free nerve ending terminal morphology is fiber type specific for A $\partial$ and $\mathrm{C}$ fibers innervating rabbit corneal epithelium. $J$ Neurophysiol. 1993;69:1779-1783.

31. Tanelian DL, Beuerman RW. Responses of rabbit corneal nociceptors to mechanical and thermal stimulation. Exp Neurol. 1984;84:165-178.

32. Belmonte C, Gallar J, Pozo MA, Rebollo I. Excitation by irritant chemical substances of sensory afferent units in the cat's cornea. J Physiol. 1991;437:709-725.

33. Guthoff RF, Wienss H, Hahnel C, Wree A. Epithelial innervation of human cornea: A three-dimensional study using confocal laser scanning fluorescence microscopy. Cornea. 2005;24:608-613.

34. Schimmelpfennig B. Nerve structures in human central corneal epithelium. Graefes Arch Clin Exp Ophthalmol. 1982;218:14-20.

35. Rózsa A, Guss R, Beuerman R. Neural remodelling following experimental surgery of the rabbit cornea. Invest Ophthal Vis Sci. 1983;24:1033-1051.

36. Beuerman R, Rózsa R. Collateral sprouts are replaced by regenerating neurites in the wounded corneal epithelium. Neurosci Lett. 1984;44:99-104.

37. Crosson C, Klyce S, Beuerman RW. Epithelial wound closure in the rabbit cornea. Invest Ophthal Vis Sci. 1986;27:464-473.

38. Chan-Ling T, Vannas A, Holden BA, O'Leary DJ. Incision depth affects the recovery of corneal sensitivity and neural regeneration in the cat. Invest Ophthal Vis Sci. 1990;31:1533-1541.

39. Chan K, Jones R, Bark D, et al. Release of neuronotrophic factor from rabbit corneal epithelium during wound healing and nerve regeneration. Exp Eye Res. 1987;45:633646.

40. de Leeuw A, Chan K. Corneal nerve regeneration: correlation between morphology and restoration of sensitivity. Invest Ophthal Vis Sci. 1989;30:1980-1990.

41. Chan-Ling T, Tervo K, Tervo TM, et al. Long-term neural regeneration in the rabbit following $180^{\circ}$ limbal incision. Invest Ophthal Vis Sci. 1987;28:2083-2088.

42. Bonnet R, Millodot M. Corneal aesthesiometry: it measurement in the dark. Am J Optom 1966;43:238-243.

43. Larson W. Electro-mechanical corneal aesthesiometer. Br J Ophthalmol. 1970;54:342347.

44. Millodot M, O'Leary DJ. Corneal fragility and its relationship to sensitivity. Acta Ophthalmol. 1981;59:820-826. 
45. Draeger J. Corneal sensitivity, measurment, and clinical importance. Vienna: SpringerVerlag; 1984.

46. Belmonte C, Acosta MC, Schmelz M, \& Gallar J. Measurement of corneal sensitivity to mechanical and chemical stimulation with a $\mathrm{CO}_{2}$ esthesiometer. Invest Ophthal Vis Sci. 1999;40:513-519.

47. Acosta MC, Gallar J, Belmonte C. Corneal sensitivity to chemical, mechanical and thermal stimuli in humans. Vision Res. 1995;35 Suppl:156.

48. Chen X, Gallar J, Pozo MA, Baeza M, Belmonte C. CO2 Stimulation of the cornea: A comparison between human sensation and nerve activity in polymodal nociceptive afferents of the cat. Eur J Neurosci. 1995;7:1154-1163.

49. Murphy PJ, Morgan P, Patel S. Corneal surface temperature change as the mode of stimulation of the non-contact corneal aesthesiometer. Cornea. 1999;18:333-342.

50. Schröder E. Prüfung der hornhauttempfindlichkeit nach operativen eingriffen. Graefes Arch Clin Exp Ophthalmol (German). 1923;111:17-32.

51. Schirmer KE, Mellor LD. Corneal sensitivity after cataract extraction. Arch Ophthalmol. 1961;65:433-436.

52. Niebroj T, Jedrzejewska K, Gruszczynska M, Patzek-Szymanska M. Stan unerwienia rogówki po operacjach usuniecia zacmy (Corneal innervation after cataract surgery). Klinika Oczna (Polish). 1981;83:495-496.

53. John T, Rao GN, Aquavella J. Corneal sensitivity in aphakic and pseudophakic eyes. CLAO J. 1988;14:101-114.

54. Guillon M, Morris JA. Corneal evaluation of prospective aphakic wearers of contact lenses. Br J Ophthalmol. 1982;66:520-523.

55. Holden BA, Polse KA, Fonn D, Mertz GW. Effects of cataract surgery on corneal function. Invest Ophthal Vis Sci. 1982;22:343-350.

56. Lyne AJ. Corneal sensitivity after surgery. Trans Am Ophthalmol Soc. 1997;102:302305.

57. Kohlhaas M, Stahlhut O, Tholuck J, Richard G. Entwicklung der hornhautsensibilität nach phakoemulsifikation mit skleralem tunnelschnitt (Corneal sensitivity after phacoemulsification with scleral tunnel incision). Klin Monatsbl Augenheilk (German). 1997;211:32-36.

58. Bogorodzki B, Nowakowska A, Omulecki W. Czucie rogowkowe u chorych poddanych zabiegowi zewnatrztorebkowego usuniecia zacmy $\mathrm{z}$ wszczepieniem sztucznej soczewki tylnokomorowej (Corneal sensitivity in patients undergoing extracapsular cataract extraction with posterior chamber IOL implantation). Klinika Oczna (Polish). 1998;100:89-94.

59. Kadonosono K, Kamata K, Kato H. Corneal sensitivity after cataract operation by corneal incision or scleral incision. Jpn J Clin Ophthalmol (Japanese). 1995;99:12591261.

60. Sitompul R, Sancoyo GS, Hutauruk JA, Gondhowiardjo T. Sensitivity change in cornea and tear layer due to incision difference on cataract surgery with either manual smallincision cataract surgery or phacoemulsification. Cornea. 2008;27 Suppl(1):S13-S18.

61. Murphy P, Patel S, Marshall J. The effect of long-term, daily contact lens wear on corneal sensitivity. Cornea. 2001;20:264-269.

62. John T. Corneal sensation after small incision, sutureless, one-handed phacoemulsification. J Cataract Refract Surg. 1995;21:425-428.

63. Kim JH, Chung JL, Kang SY, et al. Change in corneal sensitivity and corneal nerve after cataract surgery. Cornea. 2009;28 Suppl 1:S20-S25.

64. Khanal S, Tomlinson A, Esakowitz L, et al. Changes in corneal sensitivity and tear physiology after phacoemulsification. Ophthalmic Physiol Opt. 2008;28:127-134. 
65. Oh T, Jung Y, Chang D, et al. Changes in the tear film and ocular surface after cataract surgery. Jap J Ophthalmol. 2012;56:113-118.

66. Park Y, Hwang HB, Kim HS. Observation of influence of cataract surgery on the ocular surface. PLoS ONE. 2016;11:e0152460.

67. Hamada S, Moore TCB, Moore JE, et al. Assessment of the effect of cyclosporine-A $0.05 \%$ emulsion on the ocular surface and corneal sensation following cataract surgery. Cont Lens Anterior Eye. 2016;39:15-19.

68. Labiris G, Gatzioufas Z, Giarmoukakis A, et al. Liquefaction versus Torsional IP: A comparative study on endothelial cells, corneal edema and corneal sensitivity. Ophthalmic Res. 2012;49:37-42.

69. Escapini H. Degeneration and regeneration of nerves in corneal transplantation. Arch Ophthalmol. 1948;39:135-161.

70. Richter A, Slowik C, Somodi S, et al. Corneal reinnervation following penetrating keratoplasty - correlation of esthesiometry and confocal microscopy. Ger J Ophthalmol (German). 1997;5:513-517.

71. Skriver K. Reinnervation of the corneal graft. Acta Ophthalmol. 1978;56:1013-1015.

72. Rao G, John T, Ishida N, Aquavella J. Recovery of corneal sensitivity in grafts following penetrating keratoplasty. Ophthalmology. 1985;92:1408-1411.

73. Stamer L, Boknke M, Draeger J. Entwicklung der hornhautsensibilität nach keratoplastik (Corneal sensitivity in penetrating keratoplasty). Fortschr Ophthalmol (German). 1987;84:432-435.

74. Mathers WD, Jester JV, Lemp MA. Return of human corneal sensitivity after penetrating keratoplasty. Arch Ophthalmol. 1988;106:210-211.

75. Tugal-Tutkun I, Akarcay K, Kozer Bilgin L, et al. Corneal sensitivity after penetrating keratoplasty. Eur J Ophthalmol 1993;3:66-70.

76. Macalister G, Woodward E, Buckley R. The return of corneal sensitivity following transplantation. Cont Lens Anterior Eye. 1993;1993:99-104.

77. Lin X, Xu B, Sun Y, Zhong J, Huang W, Yuan J. Comparison of deep anterior lamellar keratoplasty and penetrating keratoplasty with respect to postoperative corneal sensitivity and tear film function. Graefes Arch Clin Exp Ophthalmol 2014;252:17791787.

78. Ceccuzzi R, Zanardi A, Fiorentino A, Tinelli C, Bianchi PE. Corneal sensitivity in keratoconus after penetrating and deep anterior lamellar keratoplasty. Ophthalmologica. 2010;224:247-250.

79. Darwish T, Brahma A, Efron N, O'Donnell C. Subbasal nerve regeneration after penetrating keratoplasty. Cornea. 2007;26:935-940.

80. Al-Aqaba MA, Otri AM, Fares U, Miri A, Dua HS. Organization of the regenerated nerves in human corneal grafts. Am J Ophthalmol. 2012;153:29-37.

81. Niederer RL, Perumal D, Sherwin T, McGhee CNJ. Corneal innervation and cellular changes after corneal transplantation: an in vivo confocal microscopy study. Invest Ophthal Vis Sci. 2007;48:621-626.

82. Stachs O, Zhivov A, Kraak R, et al. Structural-functional correlations of corneal innervation after LASIK and penetrating keratoplasty. J Refract Surg. 2010;26:159167.

83. Kohlhaas M, Klemn M, Böhm A, et al. Corneal sensitivity after refractive surgery. Eur J Implant Refract Surg. 1994;6:319-323.

84. Kumar RL, Koenig SB, Covert DJ. Corneal sensation after Descemet stripping and automated endothelial keratoplasty. Cornea. 2010;29:13-18.

85. Ahuja Y, Baratz KH, McLaren JW, et al. Decreased corneal sensitivity and abnormal corneal nerves in Fuchs endothelial dystrophy. Cornea. 2012;31:1257-1263. 
86. Hsu JK, Rubinfeld RS, Barry $\mathrm{P}$, et al. Anterior stromal punctures: immunohistochemical studies in human corneas. Arch Ophthalmol. 1993;111:10571063.

87. Gomes JAP, Haraguchi DK, Zambrano DU, et al. Anterior stromal puncture in the treatment of bullous keratopathy: six-month follow-up. Cornea. 2001;20:570-572.

88. Shivitz I, Arrowsmith P. Corneal sensitivity after radial keratotomy. Ophthalmology. 1988;95:827-832.

89. Linnik E. The state of corneal sensitivity in patients after anterior radial keratotomy. Oftalmol Zh (Russian). 1984;3:164-167.

90. Omoto M, Yoshida S, Miyashita H, et al. The semaphorin 3A inhibitor SM-345431 accelerates peripheral nerve regeneration and sensitivity in a murine corneal transplantation model. PLoS One. 2012;7:e47716.

91. Fukiage $C$, Nakajima T, Takayama $Y$, et al. PACAP induces neurite outgrowth in cultured trigeminal ganglion cells and recovery of corneal sensitivity after flap surgery in rabbits. Am J Ophthalmol. 2007;143:255-262.

92. Hyon JY, Hose S, Gongora C, Sinha D, O'Brien T. Effect of macrophage migration inhibitory factor on corneal sensitivity after laser in situ keratomileusis in rabbit. Korean J Ophthalmol. 2014;28:170-176.

93. Joo MJ, Yuhan KR, Hyon JY, et al. The effect of nerve growth factor on corneal sensitivity after laser in situ keratomileusis. Arch Ophthalmol. 2004;122:1338-1341.

94. Yabuta C, Oka T, Kishimoto Y, et al. Topical FK962 facilitates axonal regeneration and recovery of corneal sensitivity after flap surgery in rabbits. Am J Ophthalmol. 2012;153:651.

95. Cortina M, He J, Li N, Bazan NG, Bazan HP. Recovery of corneal sensitivity, calcitonin gene-related peptide-positive nerves, and increased wound healing induced by pigment epithelial-derived factor plus docosahexaenoic acid after experimental surgery. Arch Ophthalmol. 2012;130:76-83.

96. Koenig S, Berkowitz R, Beuerman RW, McDonald MB. Corneal sensitivity after epikeratophakia. Ophthalmology. 1983;90:1213-1218.

97. Biermann H, Grabner G, Baumgartner I, et al. Zur hornhautsensibilität nach epikeratophakie (Corneal sensitivity following epikeratophakia) Klin Monatsbl Augenheilk (German). 1992;201:18-21.

98. Kohlhaas M, Draeger J, Böhm A, et al. Zur aesthesiometrie der hornhaut nach refraktiver hornhautchirugie (Aesthesiometry of the cornea after refractive corneal surgery). Klin Monatsbl Augenheilk (German). 1992;201:221-223.

99. Böhm A, Kohlhaas $M$, Klieforth $U$, et al. Hornhautreinnervation nach lamellärer keratoplastik im vergleich zu epikeratophakie und photorefracktiver keratektomie (Corneal reinnervation after lamellar keratoplasty compared with epikeratophakia and photorefractive keratectomy). Ophthalmologe (German). 1994;91:632-637.

100. Kohlhaas M, Draeger J, Lerche R, et al. Hornhautreinnervation nach keratomileusis in situ und keratomileusis myopica - ein vergleich (A comparison of corneal reinnervation after keratomileusis myopica and keratomileusis in situ). Klin Monatsbl Augenheilk (German). 1995;206:103-106.

101. Kohlhaas M, Lerche R, Klemm M, et al. Aesthesiometry after cryo-keratomileusis and in situ keratomileusis. Eur J Implant Refract Surg. 1995;7:164-169.

102. Lerche R, Kohlhaas $\mathrm{M}$, Wegner $\mathrm{C}$, et. al. Korneale reinnervation nach lamellärer refraktiver hornhautchirurgie (Corneal reinnervation after lamellar refractive surgery). Opthalmologe (German) 1995;92:414-418. 
103. Shi W, Xie L, Li S, Yuan F, Liu H. Observation on healing process of corneal lens after epikeratophakia with confocal microscopy Zhonghua Yan Ke Za Zhi (Chinese Journal of Ophthalmology). 2002;38:295-297(in Chinese).

104. Kaminiski S, Biowki R, Lukas J, et al. Corneal sensitivity 10 years after epikeratoplasty. J Ref Surg. 2002;18:731-736.

105. Waring G, Moffitt S, Gelender H, et al. Rationale for and design of the National Eye Institute Prospective Evaluation of Radial Keratotomy (PERK) Study. Ophthalmology. 1983;90:40-58.

106. Cochener B, Le Floch G, Colin J. Les anneaux intracornéens pour la correction des faibles myopias (Intra-stromal rings for low myopic correction) $\mathrm{J} \mathrm{Fr}$ Ophthalmol (French). 1998;21:191-208.

107. Marshall J, Trokel SL, Rothery S, Schubert H. An ultrastructural study of corneal incisions induced by an excimer laser at 193nm. Ophthalmology. 1985;92:749-758.

108. Seiler T, McDonnell PJ. Excimer laser photorefractive keratectomy. Surv Ophthalmol 1995;40:89-118.

109. Thompson V, Gordon M. Use of the excimer laser in refractive surgery. Seminars Ophthalmol. 1994;9:91-96.

110. Munnerlyn CR, Koons S, Marshall J. Photorefractive keratectomy: a technique for laser refractive surgery. J Cataract Refract Surg. 1988;14:46-52.

111. Campos M, Hertzog L, Garbus J, McDonnell PJ. Corneal sensitivity after photorefractive keratectomy Am J Ophthalmol. 1992;114:51-54.

112. Ishikawa $\mathrm{T}$, Park $\mathrm{S}$, Cox $\mathrm{C}$, et al. Corneal sensation following excimer laser photorefractive keratectomy in humans. Refract Corneal Surg. 1994;10:417-422.

113. Lawrenson JG, Corbett M, O'Brart D, Marshall J. Effect of beam variables on corneal sensitivity after excimer laser photorefractive keratectomy. $\mathrm{Br} J$ Ophthalmol. 1997;81:686-690.

114. Pérez-Santonja J, Sakla H, Cardona $\mathrm{C}$, et al. Corneal sensitivity after photorefractive keratectomy and laser in situ keratomileusis for low myopia. Am J Ophthalmol 1999;127:497-504.

115. Matsui H, Kumano Y, Zushi I, et al. Corneal sensation after correction of myopia by photorefractive keratectomy and laser in situ keratomileusis. J Cataract Refract Surg. 2001;27:370-373.

116. Murphy PJ, Corbett M, O'Brart D, et al. Loss and recovery of corneal sensitivity following photorefractive keratectomy for myopia. J Ref Surg. 1999;15:38-45.

117. Trabucchi G, Brancato R, Verdi M, et al. Corneal nerve damage and regeneration after excimer laser photorefractectomy in rabbit eyes. Invest Ophthal Vis Sci. 1994;35:229235.

118. Heinz P, Bodanowitz S, Wiegand W, Kroll P. In vivo observation of corneal nerve regeneration after photorefractive keratectomy with a confocal videomicroscope. Ger J Ophthalmol (German). 1997;5:373-377.

119. Kauffmann $\mathrm{T}$, Bodanowitz $\mathrm{S}$, Hesse L, Kroll P. Corneal reinnervation after photorefractive keratectomy and laser in situ keratomileusis: an in vivo study with a confocal videomicroscope. Ger J Ophthalmol (German). 1997;5:508-512.

120. Pallikaris I, Papatzanaki M, Georgiadis A, Frenschock O. A comparative study of neural regeneration following corneal wounds induced by an argon fluoride excimer laser and mechanical wounds. Lasers Light Ophthalmol. 1990;3:89-95.

121. Ishikawa $T$, Del Cerro M, Liang Q, et al. Hypersensitivity following excimer laser ablation through the corneal epithelium. Refract Corneal Surg. 1992;8:466-474.

122. Tanelian DL, Monroe S. Altered thermal responsiveness during regeneration of corneal cold fibers. J Neurophysiol. 1995;73:1568-1573. 
123. Gallar J, Acosta MC, Moilanen JAO, Holopainen JM, Belmonte C, Tervo TMT. Recovery of corneal sensitivity to mechanical and chemical stimulation after laser in situ keratomileusis. J Refract Surg. 2004;20:229-235.

124. Murphy PJ, Stephenson C, Oliver K, Patel S, Marshall J. The effect of hyperopic photorefractive keratectomy (PRK) on corneal sensitivity: a longitudinal study. $J$ Refract Surg. 2003;19:34-39.

125. Dogru M, Katakami C, Miyashita M, et al. Ocular surface changes after excimer laser phototherapeutic keratectomy. Ophthalmology. 2000;107:1144-1152.

126. Kim W, Kim J. Change in corneal sensitivity following laser in situ keratomileusis. $J$ Cataract Refract Surg. 1999;25:368-373.

127. Chuck R, Quiros P, Perez A, McDonnell P. Corneal sensation after laser in situ keratomileusis. J Cataract Refract Surg. 2000;26:337-339.

128. Linna TU, Vesaluoma MH, Pérez-Santonja JJ, et al. Effect of myopic LASIK on corneal sensitivity and morphology of subbasal nerves. Invest Ophthalmol Vis Sci. 2000;41:393-397.

129. Battat L, Macri A, Dursun D, Pfugfelder S. Effects of laser in situ keratomileusis on tear production, clearance and the ocular surface. Ophthalmology. 2001;108:12301235.

130. Benitez-del-Castillo J, del Rio T, Iradier T, et al. Decrease in tear secretion and corneal sensitivity after laser in situ keratomileusis. Cornea. 2001;20:30-32.

131. Patel S, Pérez-Santonja J, Alió J, Murphy PJ. Corneal sensitivity and some properties of the tear film after laser in situ keratomileusis. J Ref Surg. 2001;17(17-24).

132. Toda I, Asano-Kato N, Komai-Hori Y, Tsubota K. Dry eye after laser in situ keratomileusis. Am J Ophthalmol. 2001;132:1-7.

133. Kanellopoulos A, Pallikaris I, Donnenfeld ED, et al. Comparison of corneal sensation following photorefractive keratectomy and laser in situ leratomileusis. J Cataract Refract Surg. 1997;23:34-38.

134. Kumano Y, Matsui H, Zushi I, et al. Recovery of corneal sensation after myopic correction by laser in situ keratomileusis with a nasal or superior hinge. J Cataract Refract Surg. 2003;29:757-761.

135. Nejima R, Miyata K, Tanabe $\mathrm{T}$, et al. Corneal barrier function, tear film stability, and corneal sensation after photorefractive keratectomy and laser in situ keratomileusis. Am J Ophthalmol. 2005;139:64-71.

136. Sauvageot $P$, Julio $G$, Alvarez de Toledo J, Charoenrook V, \& Barraquer R. Femtosecond laser-assisted laser in situ keratomileusis versus photorefractive keratectomy: Effect on ocular surface condition. J Cataract Refract Surg . 2017;43:167173.

137. Bragheeth M, Dua H. Corneal sensation after myopic and hyperopic LASIK, clinical and confocal microscopic study. Br J Ophthalmol. 2006;89:580-585.

138. Nassaralla B, McLeod S, Nassaralla J. Effect of myopic LASIK on human corneal sensitivity. Ophthalmology. 2003;110:497-502.

139. Sang S, Chan G, Li Y. Corneal sensitivity and dry eye after LASIK. Int J Ophthalmol. 2008;8:1987-1991.

140. Peyman GA, Sanders DR, Batlle JF, et al. Cyclosporine $0.05 \%$ ophthalmic preparation to aid recovery from loss of corneal sensitivity after LASIK. J Ref Surg. 2008;24:337343.

141. Niu LL, Zhou XT, Ding L, et al. The effects of protein-free calf blood extract for recovery of corneal nerve after LASEK and LASIK. Zhonghua Yan Ke Za Zhi. 2011;47:539-545 (Chinese). 
933

934

935

936

937

938

939

940

941

942

943

944

945

946

947

948

949

950

951

952

953

954

955

956

957

958

959

960

961

962

963

964

965

966

967

968

969

970

971

972

973

974

975

976

977

978

979

980

981

142. Donnenfeld ED, Solomon K, Perry HD, et al. The effect of hinge position on corneal sensation and dry eye after LASIK. Ophthalmology. 2003;110:1023-1029.

143. Vroman D, Sandoval H, de Castro F, et al. Effect of hinge location on corneal sensation and dry eye after laser in situ keratomileusis for myopia. J Cataract Refract Surg. 2005;31:1881-1887.

144. Huang J, Sun C, Chang C, et al. Effects of hinge position on corneal sensation and dry eye parameters after femtosecond laser-assited LASIK. J Ref Surg. 2012;28:625-631.

145. Mian SI, Li AY, Dutta S, et al. Dry eyes and corneal sensation after laser in situ keratomileusis with femtosecond laser flap creation: Effect of hinge position, hinge angle, and flap thickness. J Cataract Refract Surg. 2009;35:2092-2098.

146. Mian SI, Shtein RM, Nelson A, Musch DC. Effect of hinge position on corneal sensation and dry eye after laser in situ keratomileusis using a femtosecond laser. $J$ Cataract Refract Surg. 2007;33:1190-1194.

147. Latvala T, Barraquer-Coll C, Tervo K, Tervo TM. Corneal wound healing and nerve morphology after excimer laser in situ keratomileusis in human eyes. J Ref Surg. 1996;12:677-683.

148. Binder PS. Flap dimensions created with the IntraLase FS laser. $J$ Cataract Refract Surg. 2004;30:26-32.

149. Barequet IS, Hirsh A, Levinger S. Effect of thin femtosecond LASIK flaps on corneal sensitivity and tear function. J Ref Surg. 2008;24:897-902.

150. Yu Y, Cheng XL, Gu LQ, Jing GJ, Chen H. Femtosecond lenticule extraction for correction of myopia: clinical results and recovery of subbasal nerves. Zhonghua Yan Ke Za Zhi. 2016;52:198-205 (Chinese).

151. Reinstein DZ, Archer TJ, Gobbe M, Bartoli E. Corneal sensitivity after small-incision lenticule extraction and laser in situ keratomileusis. J Cataract Refract Surg. 8// 2015;41(8):1580-1587.

152. Gao S, Li S, Liu Y, et al. Early changes in ocular surface and tear inflammatory mediators after small-incision lenticule extraction and femtosecond laser-assisted laser in situ keratomileusis. PLoS One. 2014;9:e107370.

153. Li M, Zhou Z, Shen Y, et al. Comparison of corneal sensation between small incision lenticule extraction (SMILE) and femtosecond laser-assisted LASIK for myopia. $J$ Refract Surg. 2014;30:94-100.

154. Demirok A, Ozgurhan EB, Agca A, et al. Corneal sensation after corneal refractive surgery with small incision lenticule extraction. Optom Vis Sci. 2013;90:1040-1047.

155. Ishii R, Shimizu K, Igarashi A, et al. Influence of femtosecond lenticule extraction and small incision lenticule extraction on corneal nerve density and ocular surface: A 1year prospective, confocal, microscopic study. J Ref Surg. 2015;31:10-15.

156. Vestergaard AH, Grønbech KT, Grauslund J, et al. Subbasal nerve morphology, corneal sensation, and tear film evaluation after refractive femtosecond laser lenticule extraction. Graefes Arch Clin Exp Ophthalmol. 2013;251:2591-2600.

157. Wei S, Wang Y. Comparison of corneal sensitivity between FS-LASIK and femtosecond lenticule extraction (ReLEx flex) or small-incision lenticule extraction (ReLEx smile) for myopic eyes. Graefes Arch Clin Exp Ophthalmol. 2013;251:16451654.

158. Kung JS, Sáles CS, Manche EE. Corneal sensation and dry eye symptoms after conventional versus inverted side-cut femtosecond LASIK: A prospective randomized study. Ophthalmology. 2014;121:2311-2316.

159. Donnenfeld ED. Preservation of corneal innervation with femtosecond laser inverted sidecut flaps. Invest Ophthal Vis Sci. 2010;51:E-abstract 2855. 
160. Azar DT, Ang RT, Lee J-B, et al. Laser subepithelial keratomileusis: electron microscopy and visual outcomes of flap photorefractive keratectomy. Curr Opin Ophthalmol. 2001;12:323-328.

161. Pallikaris IG, Kalyvianaki MI, Katsanevaki VJ, Ginis HS. Epi-LASIK: Preliminary clinical results of an alternative surface ablation procedure. J Cataract Refract Surg. 2005;31:879-885.

162. Wu Y, Chu RY, Zhou XT, et al. Recovery of corneal sensitivity after laser-assisted subepithelial keratectomy. J Cataract Refract Surg. 2006;32:785-788.

163. Horwath-Winter J, Vidic B, Schwantzer G, Schmut O. Early changes in corneal sensation, ocular surface integrity, and tear-film function after laser-assisted subepithelial keratectomy. J Cataract Refract Surg. 2004;30:2316-2321.

164. Herrmann WA, Shah CP, Christoph Winkler VM, et al. Tear film function and corneal sensation in the early postoperative period after LASEK for the correction of myopia. Graefes Arch Clin Exp Ophthalmol. 2005;243:911-916.

165. Kalyvianaki MI, Katsanevaki VJ, Kavroulaki DS, et al. Comparison of Corneal Sensitivity and Tear Function Following Epi-LASIK or Laser In Situ Keratomileusis for Myopia. Am J Ophthalmol. 2006;142:669-671.

166. Lee SJ, Kim JK, Seo KY, et al. Comparison of corneal nerve regeneration and sensitivity between LASIK and Laser Epithelial Keratomileusis (LASEK). Am J Ophthalmol. 2006;141:1009-1015.

167. Darwish T, Brahma A, O'Donnell C, et al. Subbasal nerve fiber regeneration after LASIK and LASEK assessed by noncontact esthesiometry and in vivo confocal microscopy: Prospective study. J Cataract Refract Surg. 2007;33(9):1515-1521.

168. Patel SV, McLaren JW, Kittleson KM, Bourne WM. Subbasal nerve density and corneal sensitivity after laser in situ keratomileusis: Femtosecond laser vs mechanical microkeratome. Arch Ophthalmol. 2010;128:1413-1419.

169. Herrmann WA, Shah $C$, Gabler B, et al. Corneal sensation after laser epithelial keratomileusis for the correction of myopia. Graefes Arch Clin Exp Ophthalmol. 2005;243:33-37.

170. Stapleton F, Hayward KB, Bachand N, et al. Evaluation of corneal sensitivity to mechanical and chemical stimuli after LASIK: A pilot study. Eye Contact Lens. 2006;32:88-93.

171. Tuisku IS, Lindbohm N, Wilson SE, et al. Dry eye and corneal sensitivity after high myopic LASIK. J Ref Surg. 2007;23:338-342.

172. Bower KS, Sia RK, Ryan DS, Mines MJ, Dartt DA. Chronic dry eye in photorefractive keratectomy and laser in situ keratomileusis: Manifestations, incidence, and predictive factors. J Cataract Refract Surg. 2015;41:2624-2634.

173. Chao C, Golebiowski B, Zhao X, et al. Long-term effects of LASIK on corneal innervation and tear neuropeptides and the associations with dry eye. J Ref Surg. 2016;32:518-524.

174. Wollensak G, Spoerl E, Seiler T. Riboflavin/ultraviolet-A-induced collagen crosslinking for the treatment of keratoconus. Am J Ophthalmol. 2003;135:620-627.

175. Mazzotta $\mathrm{C}$, Traversi $\mathrm{C}$, Baiocchi $\mathrm{S}$, et al. Corneal healing after riboflavin ultravioletA collagen cross-linking determined by confocal laser scanning microscopy in vivo: early and late modifications. Am J Ophthalmol. 2008;146:527-533.

176. Wasilewski D, Mello GH, Moreira H. Impact of collagen crosslinking on corneal sensitivity in keratoconus patients. Cornea. 2013;32:899-902.

177. Kontadakis GA, Kymionis GD, Kankariya VP, Pallikaris AI. Effect of corneal collagen cross-linking on corneal innervation, corneal sensitivity, and tear function of patients with keratoconus. Ophthalmology. 2013;120(5):917-922. 
1032

1033

1034

1035

1036

1037

1038

1039

1040

1041

1042

1043

1044

1045

1046

1047

1048

1049

1050

1051

1052

1053

1054

1055

1056

1057

1058

1059

1060

1061

1062

1063

1064

1065

1066

1067

1068

1069

1070

1071

1072

1073

1074

1075

1076

1077

1078

1079

1080

1081

178. Lago Ade M, Nassaralla BR, Stival LR, et al. Changes in corneal sensitivity following cross-linking for progressive early-stage keratoconus. Arquivos brasileiros de oftalmologia. 2014;77:84-87.

179. Mazzotta C, Hafezi F, Kymionis G, et al. In vivo confocal microscopy after corneal collagen crosslinking. Ocul Surf. 2015;13:298-314.

180. Ünlü M, Yüksell E, Bilgihan K. Effect of corneal cross-linking on contact lens tolerance in keratoconus. Clin Exp Optom. 2016:369-374.

181. Parissi M, Randjelovic S, Poletti E, et al. Corneal nerve regeneration after collagen cross-linking treatment of keratoconus: A 5-year longitudinal study. JAMA Ophthalmol. 2016;134:70-78.

182. Spadea L, Salvatore S, Paroli MP, Vingolo EM. Recovery of corneal sensitivity after collagen crosslinking with and without epithelial debridement in eyes with keratoconus. J Cataract Refract Surg. 2015;41(3):527-532.

183. Gonzalez A, Compte RI, Martinez AL, et al. Neurotrophic keratitis after transscleral diode laser cyclophotocoagulation. Arch Soc Esp Oftalmol. 2016;91:320-326.

184. Johnson SM. Neurotrophic corneal defects after diode laser cycloablation. Am J Ophthalmol. 1998;126:725-727.

185. Raivio VE, Vesaluoma MH, Tervo TM, et al. Corneal innervation, corneal mechanical sensitivity, and tear fluid secretion after trans-scleral contact 670-nm diode laser cyclophotocoagulation. J Glaucoma. 2002;11:446-453.

186. Weigt AT, Hering IP, Marfurt C, et al. Effects of cyclophotocoagulation with a neodymium:yttrium-aluminum-garnet laser on corneal sensitivity, intraocular pressure, aqueous tear production, and corneal nerve morphology in eyes of dogs. Am J Vet Res 2002;63:906-915.

187. Broderick J. Keratopathy following retinal detachment surgery. Arch Ophthalmol. 1978;96:2021-2026.

188. Binder S, Riss B. Die Hornhautsensibilität nach Ablatiooperation (Corneal sensitivity after retinal reattachment operation). Graefes Arch Clin Exp Ophthalmol (German). 1981;217:149-154.

189. Gibson RA. Reduction of corneal sensitivity after retinal detachment surgery. $\mathrm{Br} J$ Ophthalmol. 1981;65:614-617.

190. Hung JY. Corneal sensation in retinal detachment surgery. Ann Ophthalmol. 1987;19:313-318.

191. Bouheraoua N, Hrarat L, Parsa CF, et al. Decreased corneal sensation and subbasal nerve density, and thinned corneal epithelium as a result of 360-degree laser retinopexy. Ophthalmology. 2015;122:2095-2102.

192. Auchere LC, Lux AL, Degoumois A, et al. Neurotrophic keratitis after vitrectomy and circumferential endophotocoagulation for retinal detachment. J Fr Ophtalmol. 2016;39:195-201.

193. Banerjee PJ, Chandra A, Sullivan PM, Charteris DG. Neurotrophic corneal ulceration after retinal detachment surgery with retinectomy and endolaser: a case series. JAMA Ophthalmol. 2014;132:750-752.

194. Chang Y, Yoon J, Chang J, et al. Changes in corneal and conjunctival sensitivity, tear film stability, and tear secretion after strabismus surgery. J Pediatr Ophthalmol Strabismus. 2006;43:95-99.

195. Jeon S, Park SH, Choi JS, Shin SY. Ocular surface changes after lateral rectus muscle recession. Ophthalmic Surg.Lasers Imaging. 2011;42:428-433.

196. Li Q, Fu T, Yang J, Wang Q, \& Li Z. Ocular surface changes after strabismus surgery with different incisions. Graefes Arch Clin Exp Ophthalmol. 2015;253:431-438. 
1084 Figure 1: Schematic diagram of corneal innervation showing a cross-sectional and layered

1085 views from the limbus to the central cornea and arrangement of the A delta and $\mathrm{C}$ fibres within 1086 the epithelium.

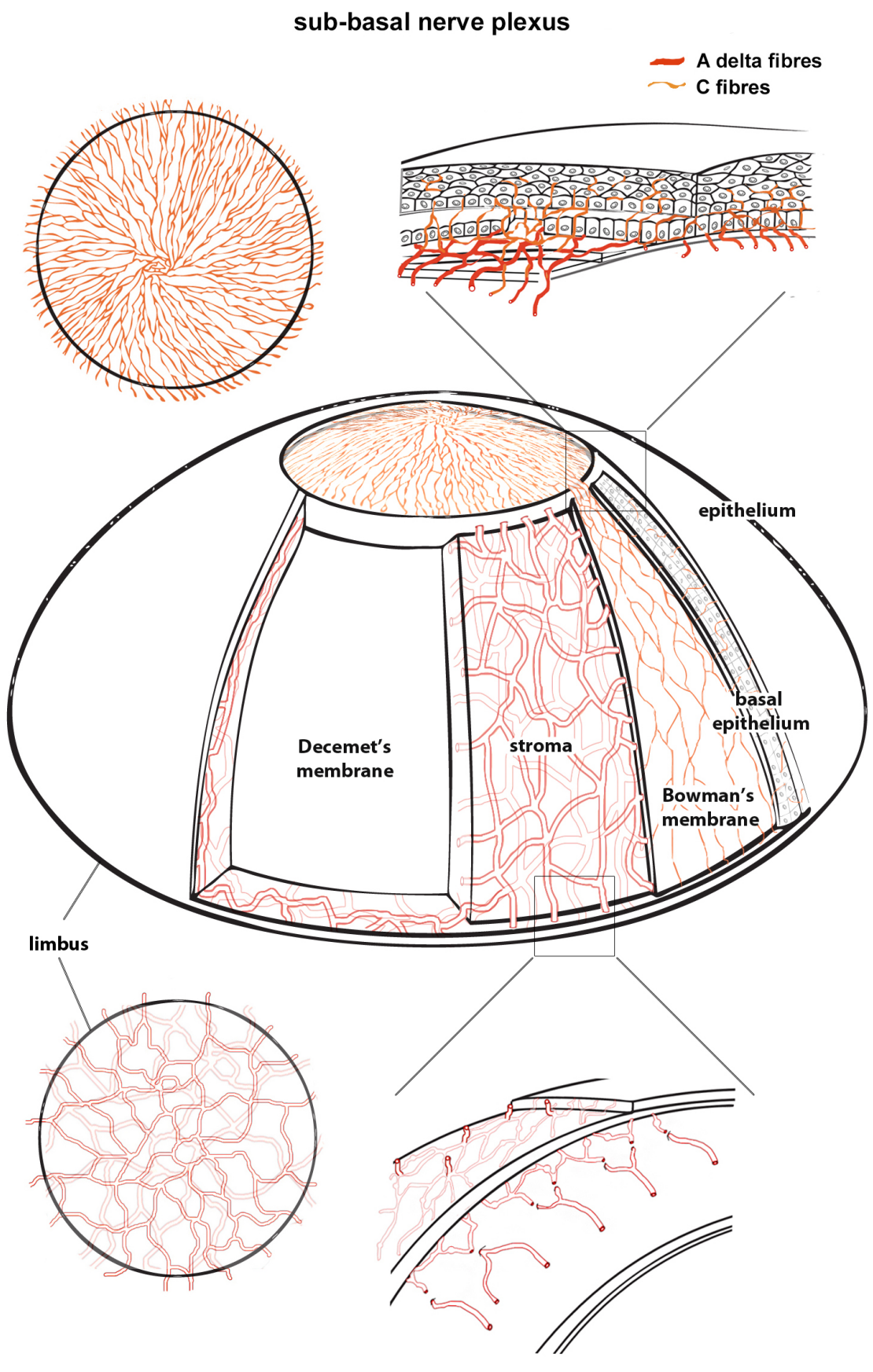

anterior stromal and sub-epithelial plexus 